\title{
INFLUENCE OF THE SOIL STRUCTURE ON SELF-POTENTIAL AND HYDRAULIC CONDUCTIVITY IN SUNGAI BATU, LEMBAH BUJANG, KEDAH
}

\author{
TAJUDEEN ADEEKO ${ }^{1}$, NORDIANA MOHD MUZTAZA* ${ }^{* 1}$ AND SAIDIN MOKHTAR ${ }^{2}$ \\ ${ }^{1}$ Universiti Sains Malaysia, School of Physics, ${ }^{2}$ Centre for Global Archaeological Research Malaysia, Universiti Sains \\ Malaysia, 11800 USM, Minden, Pulau Pinang, Malaysia.
}

*Corresponding author: mmnordiana@usm.my

Submitted final draft: 18 February 2020 Accepted: 11 May 2020

http://doi.org/10.46754/jssm.2020.12.004

\begin{abstract}
The analysis of water flow in the earth subsurface is a key issue to hydrogeology, environmental, geotechnical, and engineering studies. Disregard the effect of water flow within the soil can be more deadly and dangerous. The consciousness on the importance of soil structure has driven this study to focus on the application of geophysical and geotechnical. Self-potential result reveals two anomalies, negative and positive anomalies range from $-30 \mathrm{mV}$ to $35 \mathrm{mV}$ related to recharging and discharging activities. Negative anomaly is associated with recharge zone subsurface infiltration due to increase in dissolved inorganic materials in water but positive anomaly is associated with the discharge zone due to decrease in dissolved inorganic materials in water. Self-potential magnitude ranges from 0.3 to 0.7 . The $\%$ passing was plotted against the particle diameter, from the grain-size distribution curves result, the soil consists of medium sand $>$ coarse sand $>$ fine sand $>$ gravel $>$ very fine sand with an average hydraulic conductivity value of $0.033 \mathrm{~m} / \mathrm{s}$. Therefore, the arrangement of soil particles indicates the aggregate that the soil is loose and friable. Both hydraulic conductivity and self-potential magnitude is low. Soil structure influences self-potential, magnitude, and hydraulic conductivity in the area of water flow.
\end{abstract}

Keywords: Charging, discharging, groundwater, magnitude, soil structure, seepage.

\section{Introduction}

Self-Potential (SP) is used to describe the naturally occurring electric fields that are found everywhere in the earth (Skianis, 2012; Idris et al., 2015; Olivatiand \& Cardarelli, 2017). The self-potential method is a geophysical method that requires measuring the potential differences in millivolts $(\mathrm{mV})$ or volt correspond to a survey base, that is produced by an electric field and in the interpretation of self-potential anomalies, the + ve or -ve sign of the potential is an important diagnostic factor (Ikard et al., 2013; Adeeko et $a l ., 2018)$. In recent years the method has enjoyed a renewed interest due to improvements in both the instrumentation and field methods. Selfpotential generated by groundwater flows with respect to a solid, and it is the only geophysical phenomenon directly related to the transport of subsurface water and the self-potential can also be called the 'Streaming Potential' (Alamta et al., 2012; Emujakporue, 2016). The self-potential method is used almost exclusively to map the flow of groundwater through porous materials for engineering, environmental or groundwater geophysics and these can be unconsolidated porous soil deposits or fractures in weathered bedrock (Martínez-Pagán et al., 2010; Moore et al., 2011; Giampaolo et al., 2016). The selfpotential method involves measurement of electric potential associated with this electric field and using them to infer the behaviour and properties of the hydraulic system.

The ability of the material to transmit fluid through fractures and pore spaces in the presence of an applied hydraulic gradient is known as Hydraulic conductivity (Nimmo et al., 2009; Salarashayeri \& Siosemarde, 2012). Darcy's Law defined hydraulic conductivity as the ratio of the average velocity of a fluid through a crosssectional area to the applied hydraulic gradient (Daniel, 1989; Odong, 2008). Hydraulic conductivity is used for estimating groundwater 
recharge through the vadose zone (Reynolds \& Elrick, 1990; Fetter, 2001). Hydraulic conductivity values are used for modelling by hydrologists, and hydraulic conductivity values use it to determine soil health or how water flows through the soil at different field sites for prediction by researchers. Hydraulic conductivity is used to determine irrigation rates or nutrient leaching or erosion prediction in agricultural decisions (Nimmo et al., 2009). Essentially, to know how water will move within the soil system, hydraulic conductivity must understand because it governs water flow. The particle size distribution, soil texture, tortuosity, roughness, degree of interconnection of water-conducting pores, and shape are the factors hydraulic conductivity depends on. Soil texture, coarser textured soils have higher hydraulic conductivities than fine-textured soils. However, structured soil has large pores, while structureless soil has smaller pores (Reynolds \& Elrick, 1990).

Groundwater is water that fills the cracks and areas between soil particles, sand grains, and rock (Song et al., 2009; Bohling \& Butler, 2010; Jardani et al., 2006; Rosas et al., 2014; Voytek et al., 2016). Each drop of rain that soaks into the soil moves downward to fill these areas and gaps, thereby turning into groundwater keep within the soil and rock (Alamta et al., 2012; Brauchler et al., 2013; Soueid et al., 2014; Gao et al., 2018). The places during which surface water infiltrates into the soil square measure recharge zones, wherever groundwater is found and therefore the places during which groundwater seeps or flows into surface water square measure discharge zones (Maineult et al., 2006; Linde et al., 2011; Essa \& Elhussein, 2017; Muhammad, 2019). Groundwater happens both in loosely aggregated and unconsolidated materials, like sand and gravel, and in consolidated rocks, like sandstone, limestone, granite, and basalt (Fagerlund \& Heinson, 2003; Giampaolo et al., 2016; Mohd et al., 2019). In the capability to move and store groundwater the earth matter varies, the earth materials' strength to move groundwater varies by vital orders. It is also regulated by the interconnection, size, shape, and volume of areas between solids within the materials of various sorts, e.g. the interconnected pore areas in finer-grained sediments smaller than those in sand and gravel (Putvance, 2000; Odong, 2008; Nabi-Sichani \& Sepaskhah, 2012). Therefore the hydraulic conductivity $(\mathrm{K})$ of the finer-grained materials is smaller than the hydraulic conductivity $(\mathrm{K})$ of sand and gravel (Morin, 2006; Lopez et al., 2015; Harry et al., 2018). Water flow through soil is influenced by its structure, where connecting pores are the natural pathway for water and air exchange (Revil \& Leroy, 2004; Alakayleh et al., 2018). The total porosity not only influenced water movement through the soil, however, essentially by the size of the pores, corresponding to the amount of sand, silt, and clay dictate such property (Straface et al., 2010; Cabalar \& Akbulut, 2016; Bol'eve et al., 2007). Soil texture is the main factor that affects soil structure origination. Therefore, there a need to review the influence of the soil structure on self-potential and hydraulic conductivity for groundwater flow in Sungai Batu, Lembah Bujang, Kedah as the population and industries increase, which can affect the usage of water and cause infiltration of pollutants and subsequent contamination of groundwater derived from refuse dump, improper use and disposal of pesticides that result in serious environmental hazard and loss of life and properties due to flood and landslide, if not properly studied.

\section{Materials and Methods}

\section{Geology of Kedah and study area}

Kedah is situated on the northwest coast of Peninsular Malaysia, bordered by the Straits of Malacca on the west, by Penang and Perak in the south, and by Perlis in the north. In the central and south Kedah, Mahang Formation is exposed. Fauziah et al., (2006); Khodzori et al., (2019) divided the Mahang Formation into four lithofacies: (1) dominant argillaceous facies (2) subsidiary arenaceous facies (3) minor siliceous facies that grades into the argillaceous (4) restricted calcareous facies. In the Mahang area, Khodzori et al., (2019) divided the Mahang 
Formation into four members; dark grey shale or sandstone, dark graptolite-bearing shale, flagstone and chert, massive dark mudstone and red and grey laminated shale as indicated in Figure 1. In Peninsular Malaysia, the oldest civilization site is Kedah as shown by archaeological evidence.

The study was done in the archaeological site, Sungai Batu, Lembah Bujang, Kedah and the area is surrounded by palm trees on all sides and has nearly flat topography. There are four (4) survey lines (SB1 to SB4) spaced over $30 \mathrm{~m}$ x $9 \mathrm{~m}$ for the self-potential survey, the electrode spacing is $2 \mathrm{~m}$ using a fixed base array between latitude $5.69400 \mathrm{~N}-5.694265 \mathrm{~N}$ and longitude 100.454582E-100.4547866E. The soil samples were collected at different locations from SS1 to SS3. The soil sample one (SS1) is located at 2.5 $\mathrm{m}$ distance in SB2 with $3.5 \mathrm{~m}$ depth maximum, the soil sample two (SS2) is located at $21 \mathrm{~m}$ distance in SB2 with $3.5 \mathrm{~m}$ depth maximum, and the soil sample three (SS3) is located at $7.5 \mathrm{~m}$ distance in SB3 with $1 \mathrm{~m}$ depth maximum due to constraint as shown in Figure 2. The borehole (BH10) information from the area which helps in the interpretation of the soil that consists of sand, sandy clay, and gravel at the top and at the center with sandy clay with little gravel and at the bottom consisting of mottle dry, content little weathered and gravel deposit. Also, the borehole record shows that the area consists of dark brownish sandy clay, reddish or yellowish clay and shale material which are very firm dry conditions.

\section{Experimental design}

\section{Self-potential}

A simple SP survey consists of a base electrode and a roving electrode to determine potential differences in a grid survey or along profile lines. The required equipment merely includes a pair of non-polarising copper $(\mathrm{Cu})$ electrodes, $\mathrm{CuSO}_{4}$ solution, wire, small hoe, measuring tape, $12 \mathrm{~V}$ battery, and ABEM SAS40000 Terrameter. The electrode in contact with the ground surface was the non-polarizing type, also called porous pots (Revil et al., 2003; Srivastava \& Agarwal, 2009; Malama, 2014; Essa \& Elhussein, 2017). Porous pots are metal electrodes suspended in a supersaturated solution of their own salts (copper electrode suspended in copper sulfate) within a porous container (Jouniaux et al., 2009; Roudsari \& Beirollahi, 2015; Jougnot et al., 2015). The background voltage is as small as possible when these pots produce very low electrolytic contact

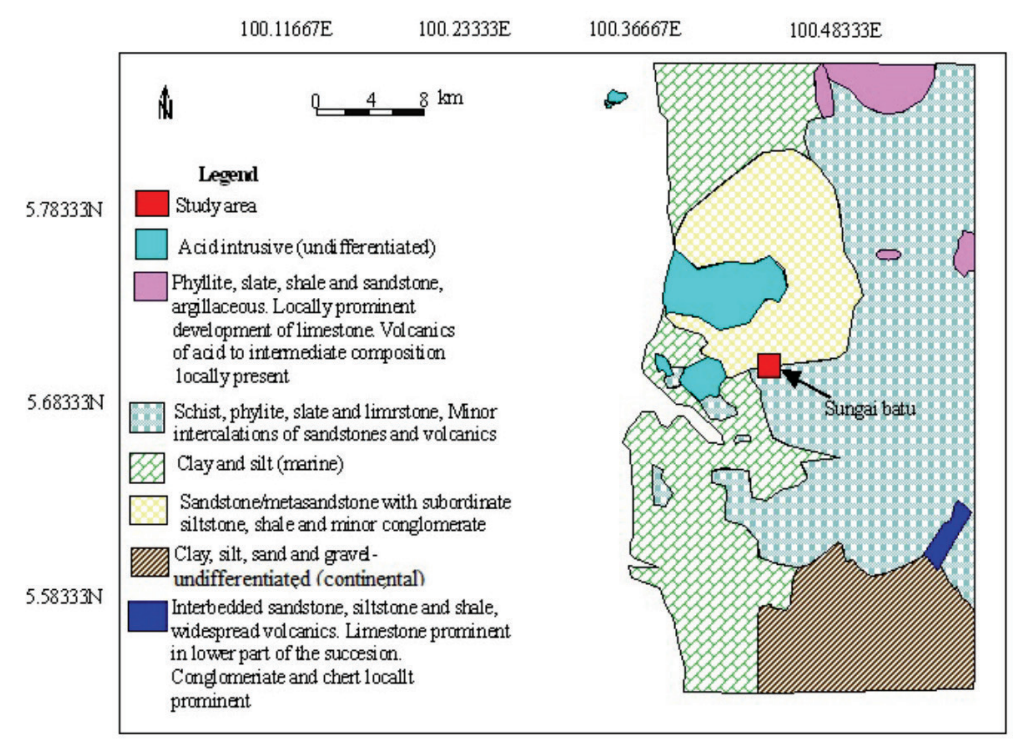

Figure 1: Geological map of Kedah and the study area 


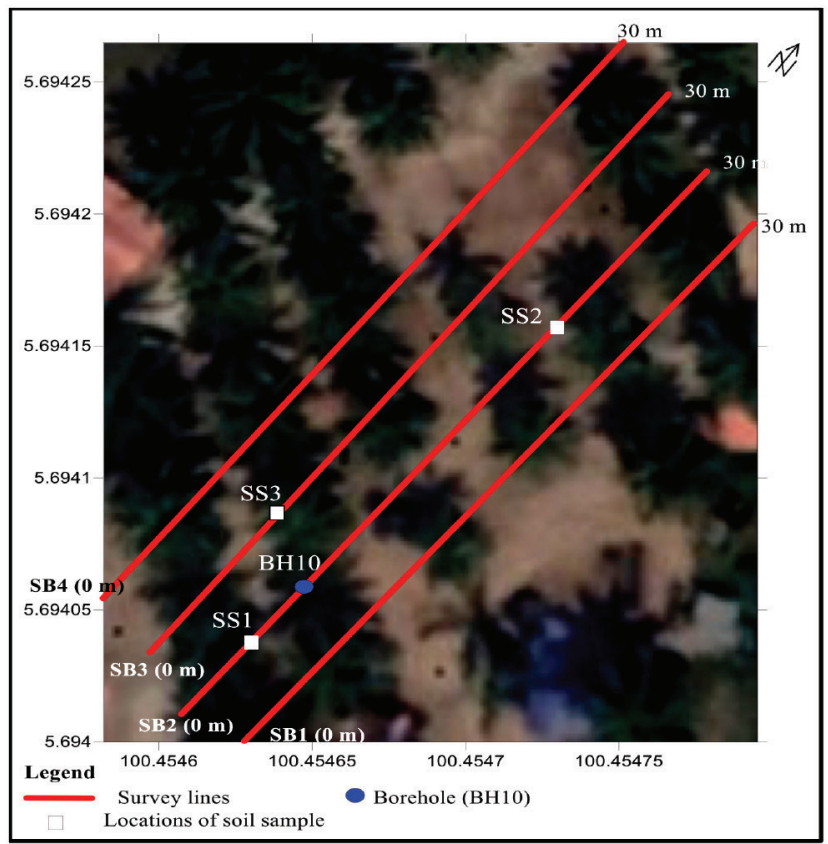

Figure 2: Study area shows the survey lines and soil sample locations in Sungai Batu

(Google Earth 2018)

potential. Sealed porous pots are used to avoid evaporation of the salt solution (Tanguy et al., 2011; Gokturkler \& Balkaya, 2012; Mehanee, 2015) and they keep the supersaturated solutions for a longer time. Only one set of a base and the moving electrode is used for the measurement along the profile line. The Potential amplitude or total field method (fixed base) configuration was adopted, keeping one electrode fixed at a base station away from the survey line at about $15 \mathrm{~m}$ and the rover electrode. The voltage between a based liquid-junction electrode and a mobile one is a measure, and multiple readings ( 4 cycles) are taken and the average is found using ABEM SAS4000 Terameter. When water reacts as an electrolyte and as a different minerals' solvent, the potential is generated by water flow, which is the common factor responsible for selfpotential (Linde et al., 2011; Mao et al., 2015; Muztaza et al., 2018). The potential difference was generated by electrokinetic potential and the electrokinetic potential: Fluid (electrolyte) flow in a porous medium generates potential along the flow path known as electrofiltration, streaming potential and which is caused by electrokinetic coupling between the fluid ions and the walls of the capillary/porous medium. $\mathrm{Ek}$ is an electrokinetic potential generated given by Eq. 1

$$
E_{k}=\frac{\epsilon \rho C_{E} \Delta P}{4 \pi \eta}
$$

Where, $\varepsilon=$ Dielectric permittivity of pore fluid; $\rho$ $=$ Electrical resistivity of pore fluid; $\mathrm{CE}=$ Electrofiltration coupling coefficient; $\Delta \mathrm{P}=$ Pressure difference; $\eta=$ Dynamic viscosity of pore fluid; $E_{k}$ is opposite to the direction of the electrolyte flow and $E_{k}$ normally provides amplitudes of some $\mathrm{mV}$ to several hundred $\mathrm{mV}$. $E_{k}$ is associated with the flow of subsurface water as indicated in Eq 1.

\section{Sieve Analysis and Grain-Size Distributions (GSDS)}

Sieving is done using quantity of dry soil by a set of British Standard Soil Classification System (BS) BS410/1986 sieve with mesh sizes (No 1/4", 4, 5, 6, 7, 8, 10, 12, 14, 16, 18, $20,25,30,35,40,45,50,60,70,80,100,120$, $140,170,200,230$ corresponding to equivalent 
diameter $6.30,4.75,4.00,3.35,2.80,2.36,2.00$, $1.70,1.40,1.18,1.00,0.85,0.71,0.60,0.50$, $0.43,0.36,0.30,0.25,0.21,0.18,0.15,0.13$, $0.11,0.09,0.075,0.063 \mathrm{~mm}$ respectively. The soil sample is then sieved. The amount of soil on each sieve is weighed and the percentage of the entire material that is passing through each sieve is used to plot the grain-size curve, to determine the soil type and hydraulic conductivity. Sorted soil with larger grains will have high hydraulic conductivity (Hussain \& Nabi, 2016; Alakayleh et al., 2018). This is because the void between the larger grains is filled up with smaller grains.

The hydraulic conductivity $(\mathrm{K})$ is a measure of the ability of the soil to transmit water and is an important parameter for studying the subsurface flow and transport problems (Chapuis, 2012; Hussain \& Nabi, 2016). From grain size to estimate $\mathrm{K}$ the equations normally apply two metrics from a grain size distribution plot: the $10 \%$ of the sample is finer ( $90 \%$ is coarser) of the grain diameter " $\mathrm{D}_{10}$ " and $60 \%$ of the sample is finer ( $40 \%$ is coarser) of the grain diameter " $\mathrm{D}_{60}$ ". $\mathrm{D}_{10}$ is frequently taken as the effective diameter of the sample while the ratio $\mathrm{C}_{\mathrm{U}}=\mathrm{D}_{60} /$ $\mathrm{D}_{10}$ is known as the coefficient of uniformity and $\mathrm{C}_{\mathrm{C}}=\mathrm{D}_{30}{ }^{2} / \mathrm{D}_{60} \times \mathrm{D}_{10}$ is known as the coefficient of curvature (Carrier, 2003; Ishaku et al., 2011). The soil used in this research is saturated soil and sandy, and as a result, the standard formula given by Hazen is used to calculate hydraulic conductivity of the soil from a grain size distribution plot as shown in Eq 2.

$$
\mathrm{K}=\mathrm{C}_{\mathrm{H}}\left(\mathrm{D}_{10}\right)^{2}
$$

where $\mathrm{K}=$ hydraulic conductivity $(\mathrm{m} / \mathrm{s}) ; \mathrm{C}_{\mathrm{H}}=$ Hazen empirical coefficient; and $\mathrm{D}_{10}=$ is grain diameter corresponds in grain size curve at 10 $\%$ of content $(\mathrm{mm})$. The value of $\mathrm{C}_{\mathrm{H}}$ is usually assumed to be between 1.0 - 1.5 (Hazen, 1982; Carrier 2003; Salarashayeri \& Siosemarde, 2012).

\section{Results and Discussion}

The $\%$ passing was plotted against the particle diameter, from the grain-size distribution curves with the aim to measure the particle size distribution of undisturbed soil samples from
Sungai Batu Kedah, using British Standard (BS410) sieve. The soils are classified into soiltype groups according to particle size, such as gravel, coarse sand, medium sand, fine sand, and very fine sand. The raw data obtained from selfpotential were input into Microsoft excel and then processed using Surfer 8 software. The selfpotential result reveals two anomalies, negative and positive anomalies ranging from $-30 \mathrm{mV}$ to $35 \mathrm{mV}$ related to recharging and discharging activities. A grading curve is a useful aid to soil classification/description. Results of the grading curve were shown in Figures 3-5 for soil sample taken at $2.5 \mathrm{~m}$ distance is $\mathrm{SS} 1$ while the soil sample taken at $21 \mathrm{~m}$ distance is SS2 and the soil sample taken at $7.5 \mathrm{~m}$ distance is $\mathrm{SS} 3$ and self-potential is shown in Figure 6 with the aim of relating the calculated hydraulic conductivity (K) with the self-potential magnitude which has not been researched on.

Figure 3 shows all the soil sample one (SS1) for $2.5 \mathrm{~m}$ distance from $0.5 \mathrm{~m}, 1 \mathrm{~m}, 1.5 \mathrm{~m}, 2 \mathrm{~m}$, $2.5 \mathrm{~m}, 3 \mathrm{~m}$, and $3.5 \mathrm{~m}$ depth.

From soil sample one (SS1) at $0.5 \mathrm{~m}$ depth as shown in Figure 3a, the investigated soil is classified based on the grain-size distribution curve which is as follows: $18.4 \%$ gravel, $31.2 \%$ coarse sand, $31.9 \%$ medium sand, $17.6 \%$ fine sand and $0.9 \%$ very fine sand with coefficient of uniformity value of 7.39 , coefficient of curvature value of 1.85 and hydraulic conductivity value of $0.053 \mathrm{~m} / \mathrm{s}$. This shows that the soil at this depth is more of medium sand and coarse sand than gravel and fine sand and less of very fine sand. The self-potential has value $<-15 \mathrm{mV}$ and with increased dissolved inorganic materials in the water, thus giving low self-potential.

For soil sample one (SS1) at $1 \mathrm{~m}$ depth, the investigated soil is classified based on the grain-size distribution curve as shown in Figure 3b: $11.6 \%$ gravel, $31.3 \%$ coarse sand, $34.2 \%$ medium sand, $21.9 \%$ fine sand and $1.0 \%$ very fine sand with coefficient of uniformity value of 13.5 , coefficient of curvature value of 1.02 and hydraulic conductivity value of $0.029 \mathrm{~m} / \mathrm{s}$. At this depth, it shows that the soil is more of medium sand and coarse sand than fine sand 
and gravel and less of very fine sand. The selfpotential has value $<-15 \mathrm{mV}$ and self-potential is low when the dissolved inorganic materials in water increases.

Soil sample one (SS1) at $1.5 \mathrm{~m}$ depth the investigated soil is classified based on the grain-size distribution curve as shown in Figure 3c: $5.6 \%$ gravel, $24.6 \%$ coarse sand, $31.9 \%$ medium sand, $37.1 \%$ fine sand and $0.8 \%$ very fine sand with coefficient of uniformity value of 9.64 , coefficient of curvature value of 0.48 and hydraulic conductivity value of $0.020 \mathrm{~m} / \mathrm{s}$. At this depth, the soil shows more of fine sand and medium sand than coarse sand and less of gravel and very fine sand. The self-potential has value $<-15 \mathrm{mV}$ and as the dissolved inorganic materials in water increases give low selfpotential.

Soil sample one (SS1) at $2 \mathrm{~m}$ depth, the investigated soil is classified based on the grainsize distribution curve with the following as shown in Figure 3d: 10.9\% gravel, 33.9\% coarse sand, $32.4 \%$ medium sand, $21.8 \%$ fine sand and $1.0 \%$ very fine sand with coefficient of uniformity value of 13.11, coefficient of curvature value of 0.59 and hydraulic conductivity value of 0.032 $\mathrm{m} / \mathrm{s}$. It shows that the soil at this depth is more of coarse sand and medium sand than fine sand and gravel and less of very fine sand. The selfpotential has value $<-15 \mathrm{mV}$ and as the dissolved inorganic materials in water increases give low self-potential.

Soil sample one (SS1) at $2.5 \mathrm{~m}$ depth the investigated soil is classified based on the grainsize distribution curve with the following as shown in Figure 3e: 7.8\% gravel, 30.3\% coarse sand, $33.2 \%$ medium sand, $28.1 \%$ fine sand and $0.7 \%$ very fine sand with coefficient of uniformity value of 12.67 , coefficient of curvature value of 0.88 and hydraulic conductivity value of 0.023 $\mathrm{m} / \mathrm{s}$. The soil at this depth shows more medium sand, coarse sand, and fine sand than gravel and less of very fine sand. The self-potential has value $<-15 \mathrm{mV}$ and as the dissolved inorganic materials in water increases give low selfpotential.
Soil sample one (SS1) at $3 \mathrm{~m}$ depth the investigated soil is classified based on the grainsize distribution curve with the following as shown in figure $3 \mathrm{f}$ : $7.1 \%$ gravel, $25.3 \%$ coarse sand, $35.4 \%$ medium sand, $31.4 \%$ fine sand and $0.8 \%$ very fine sand with coefficient of uniformity value of 10.71 , coefficient of curvature value of 0.69 and hydraulic conductivity value of 0.020 $\mathrm{m} / \mathrm{s}$. It shows that the soil at this depth is more of medium sand, fine sand, and coarse sand than gravel and less of very fine sand. The selfpotential has value $<-15 \mathrm{mV}$ and as the dissolved inorganic materials in water increases give low self-potential.

Soil sample one (SS1) at $3.5 \mathrm{~m}$ depth, the investigated soil is classified based on the grainsize distribution curve with the following as shown in Figure 3g: 8.7\% gravel, 29.6\% coarse sand, $34.3 \%$ medium sand, $26.7 \%$ fine sand and $0.7 \%$ very fine sand with coefficient of uniformity value of 11.85 , coefficient of curvature value of 0.82 and hydraulic conductivity value of 0.026 $\mathrm{m} / \mathrm{s}$. At this depth, the soil shows more medium sand, coarse sand and fine sand than gravel and less of very fine sand. The self-potential has value $<-15 \mathrm{mV}$ and as the dissolved inorganic materials in water increases give low selfpotential.

Figure 4: All the soil sample one (SS2) for $21 \mathrm{~m}$ distance from $0.5 \mathrm{~m}, 1 \mathrm{~m}, 1.5 \mathrm{~m}, 2 \mathrm{~m}, 2.5$ $\mathrm{m}, 3 \mathrm{~m}$, and $3.5 \mathrm{~m}$ depth

Soil sample two (SS2) at $0.5 \mathrm{~m}$ depth as shown in figure $4 \mathrm{a}$; soil is classified into soiltype groups according to size which consists of $26.7 \%$ gravel, $26.7 \%$ coarse sand, $30.4 \%$ medium sand, $14.8 \%$ fine sand and $1.1 \%$ very fine sand with coefficient of uniformity value of 12.31 , coefficient of curvature value of 1.2 and hydraulic conductivity value of $0.068 \mathrm{~m} / \mathrm{s}$. It shows that the soil at this depth is more of medium sand, coarse sand, and gravel than fine sand and less of very fine sand. The selfpotential has value $<5 \mathrm{mV}$ and as the dissolved inorganic materials in water increases give low self-potential. 

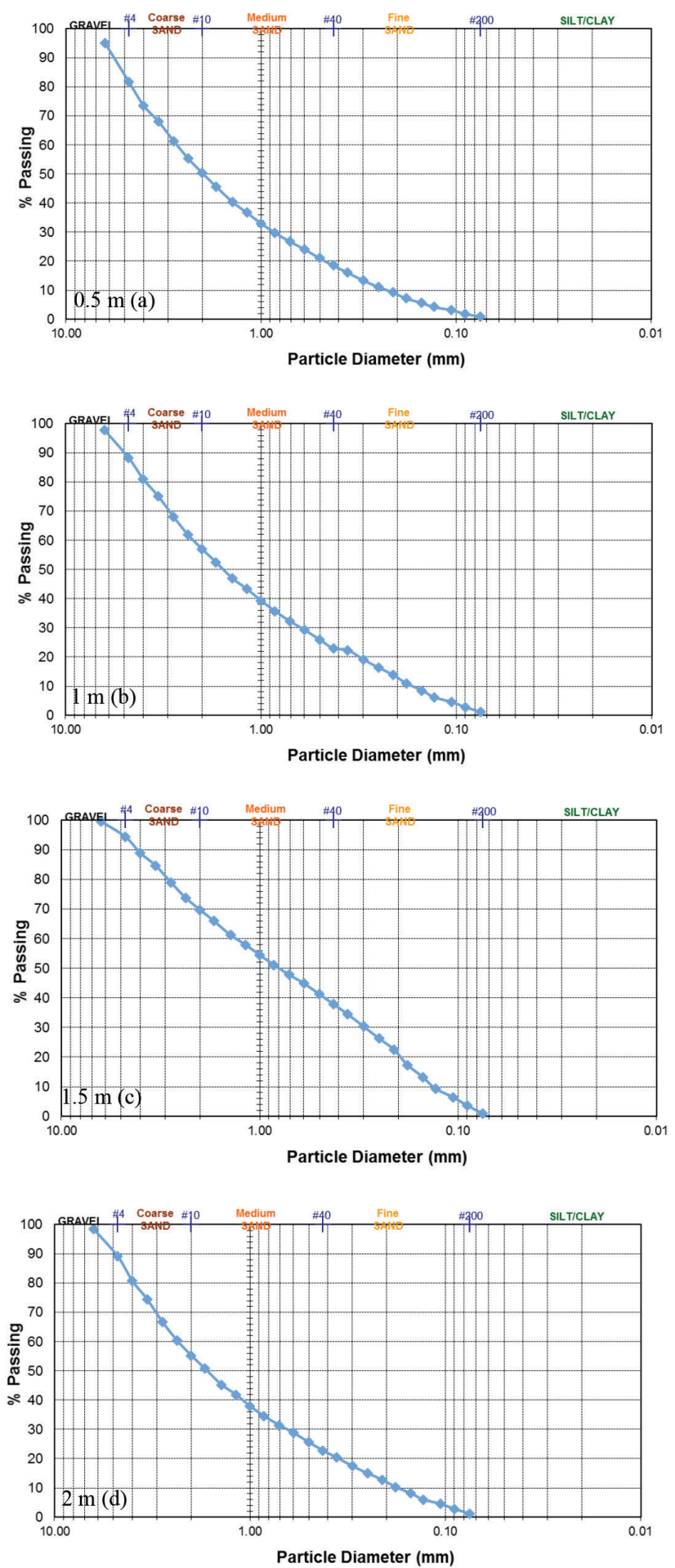

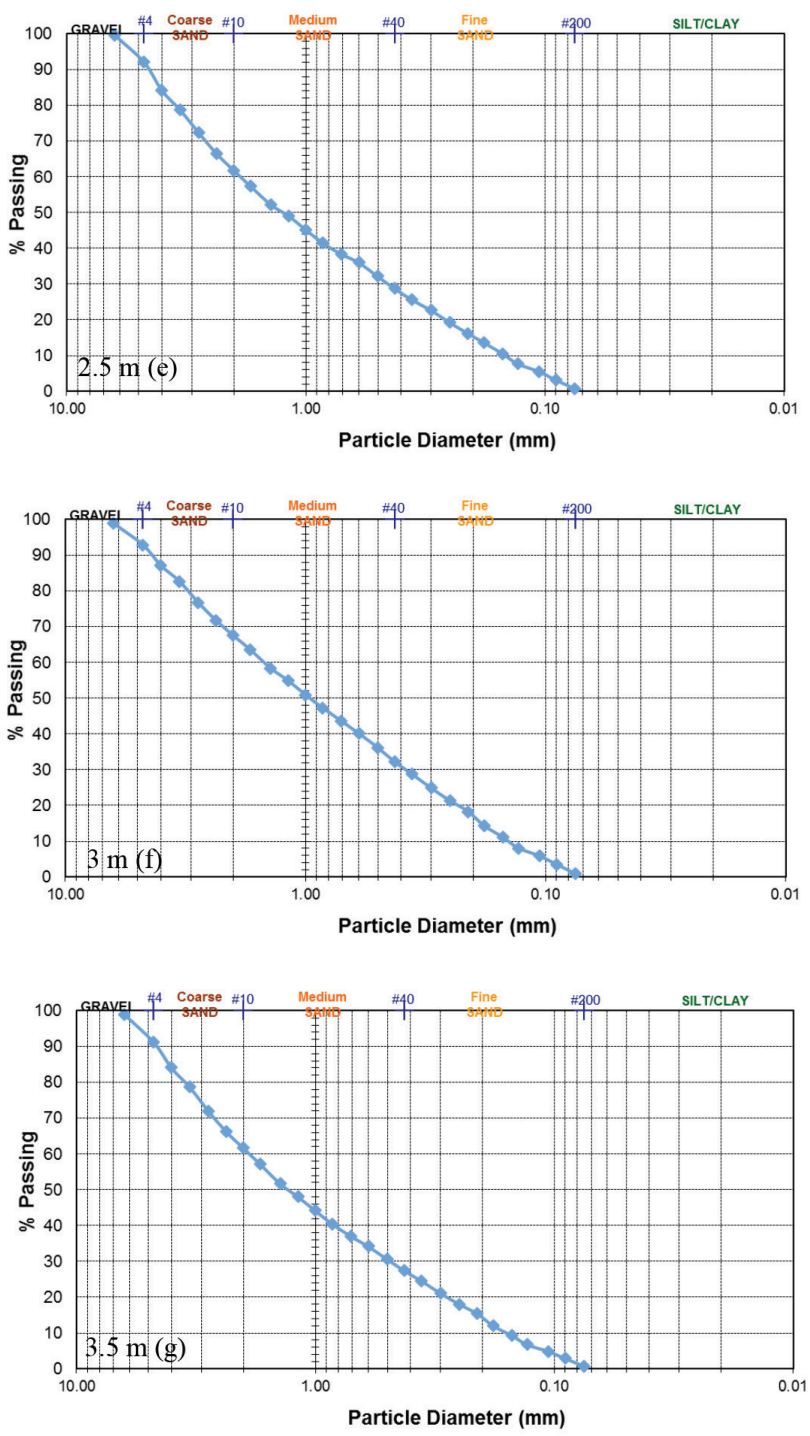

Figure 3: Grain size distribution curve at $2.5 \mathrm{~m}$ distance for soil sample one (SS1) at depth of (a) $0.5 \mathrm{~m}$ (b) 1 $\mathrm{m}$ (c) $1.5 \mathrm{~m}$ (d) $2 \mathrm{~m}$ (e) $2.5 \mathrm{~m}$ (f) $3 \mathrm{~m} \mathrm{(g)} 3.5 \mathrm{~m}$

Soil sample two (SS2) at $1 \mathrm{~m}$ depth soil is classified into soil-type groups according to size as shown in Figure $4 \mathrm{~b}$ which consists of $13.6 \%$ gravel, $30.8 \%$ coarse sand, $33.7 \%$ medium sand, $20.0 \%$ fine sand and $1.4 \%$ very fine sand with coefficient of uniformity value of 12.42 , coefficient of curvature value of 1.06 and hydraulic conductivity value of $0.036 \mathrm{~m} / \mathrm{s}$. At this depth, the soil shows more of medium sand and coarse sand than fine sand and gravel and less of very fine sand. The self-potential has value $<5 \mathrm{mV}$ and as the dissolved inorganic materials in water increases give low selfpotential.

Soil sample two (SS2) at $1.5 \mathrm{~m}$ depth soil is classified into soil-type groups according to size as shown in Figure 4c which consists of $19.0 \%$ gravel, $24.3 \%$ coarse sand, $27.2 \%$ medium sand, $28.2 \%$ fine sand and $1.2 \%$ very fine sand with coefficient of uniformity value 
of 15.73, coefficient of curvature value of 0.57 and hydraulic conductivity value of $0.023 \mathrm{~m} / \mathrm{s}$. The soil at this depth shows more of fine sand, medium sand, and coarse sand than gravel and less of very fine sand. The self-potential has value $<5 \mathrm{mV}$ and as the dissolved inorganic materials in water increases give low selfpotential.

Soil sample two (SS2) at $2 \mathrm{~m}$ depth soil is classified into soil-type groups according to size as shown in Figure $4 \mathrm{~d}$ which consists of $12.7 \%$ gravel, $33.2 \%$ coarse sand, $31.4 \%$ medium sand, $20.9 \%$ fine sand and $1.8 \%$ very fine sand with coefficient of uniformity value of 13.78 , coefficient of curvature value of 1.07 and hydraulic conductivity value of $0.032 \mathrm{~m} / \mathrm{s}$. It shows that the soil at this depth is more of coarse sand and medium sand than fine sand and gravel and less of very fine sand. The selfpotential has value $<5 \mathrm{mV}$ and as the dissolved inorganic materials in water increases give low self-potential.

Soil sample two (SS2) at $2.5 \mathrm{~m}$ depth the investigated soil is classified based on the grainsize distribution curve with the following as shown in figure 4e: $18.9 \%$ gravel, $28.9 \%$ coarse sand, $28.5 \%$ medium sand, $21.2 \%$ fine sand and $2.5 \%$ very fine sand with coefficient of uniformity value of 16.75 , coefficient of curvature value of 0.84 and hydraulic conductivity value of 0.026 $\mathrm{m} / \mathrm{s}$. The soil at this depth shows more coarse sand and medium sand than fine sand and gravel and less of very fine sand. The self-potential has value $<5 \mathrm{mV}$ and as the dissolved inorganic materials in water increases give low selfpotential.

Soil sample two (SS2) at $3 \mathrm{~m}$ depth: the investigated soil is classified based on the grainsize distribution curve with the following as shown in Figure 4f: 17.8\% gravel, 31.9\% coarse sand, $29.0 \%$ medium sand, $20.1 \%$ fine sand and $1.1 \%$ very fine sand with coefficient of uniformity value of 14.74 , coefficient of curvature value of 1.17 and hydraulic conductivity value of 0.036 $\mathrm{m} / \mathrm{s}$. It shows that the soil at this depth is more of coarse sand and medium sand than fine sand and gravel and less of very fine sand. The selfpotential has value $<5 \mathrm{mV}$ and as the dissolved inorganic materials in water increases give low self-potential.

Soil sample two (SS2) at $3.5 \mathrm{~m}$ depth: the investigated soil is classified based on the grainsize distribution curve with the following as shown in Figure 4g: 15.6\% gravel, 28.3\% coarse sand, $31.8 \%$ medium sand, $22.7 \%$ fine sand and $1.6 \%$ very fine sand with coefficient of uniformity value of 13.88 , coefficient of curvature value of 0.87 and hydraulic conductivity value of 0.029 $\mathrm{m} / \mathrm{s}$. At this depth, the soil shows more medium sand, coarse sand and fine sand than gravel and less of very fine sand. The self-potential has value $<5 \mathrm{mV}$ and as the dissolved inorganic materials in water increases, a give low selfpotential is seen.

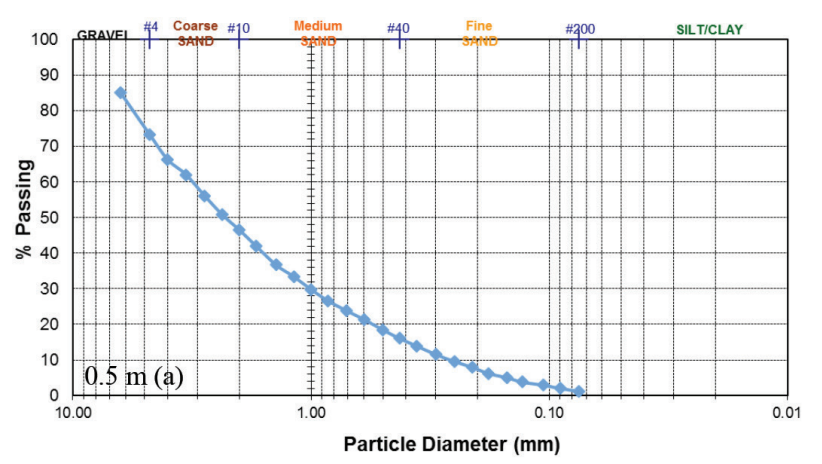



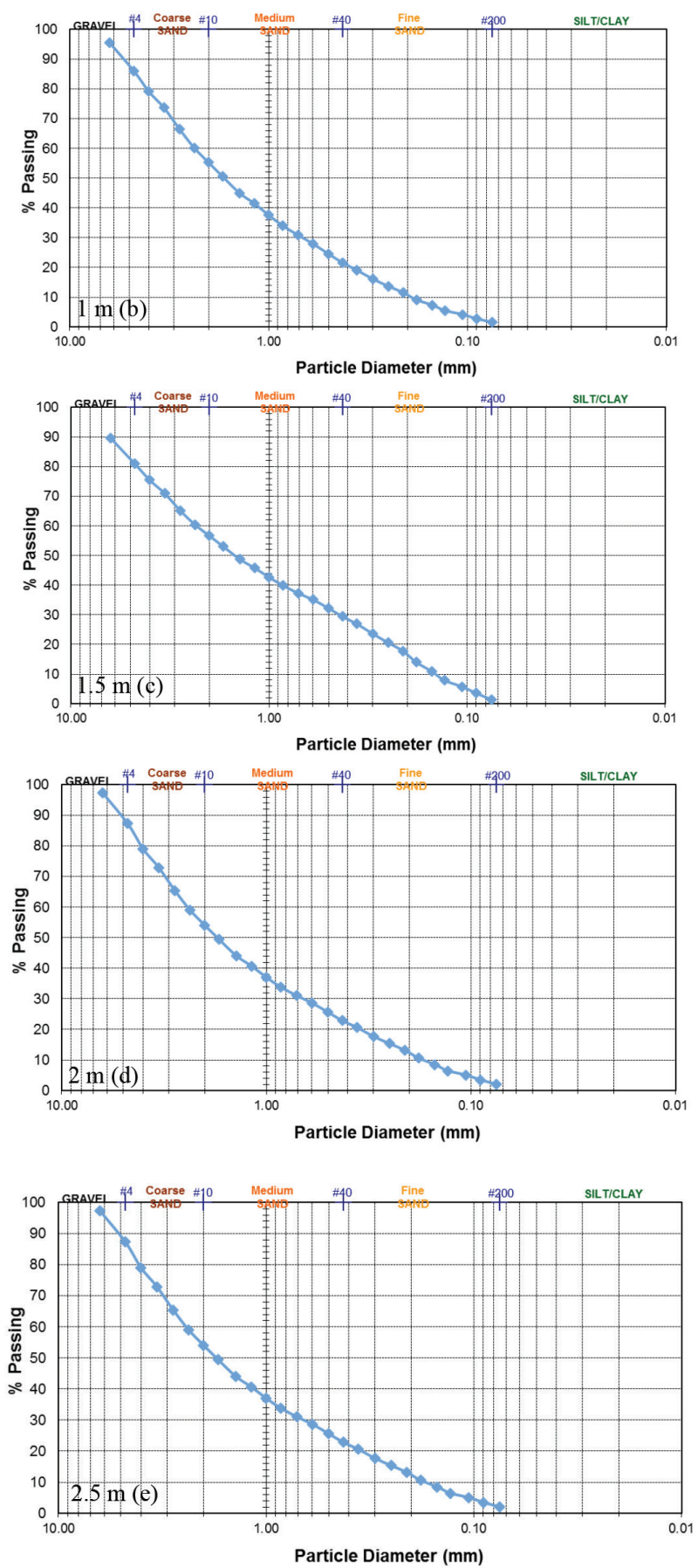

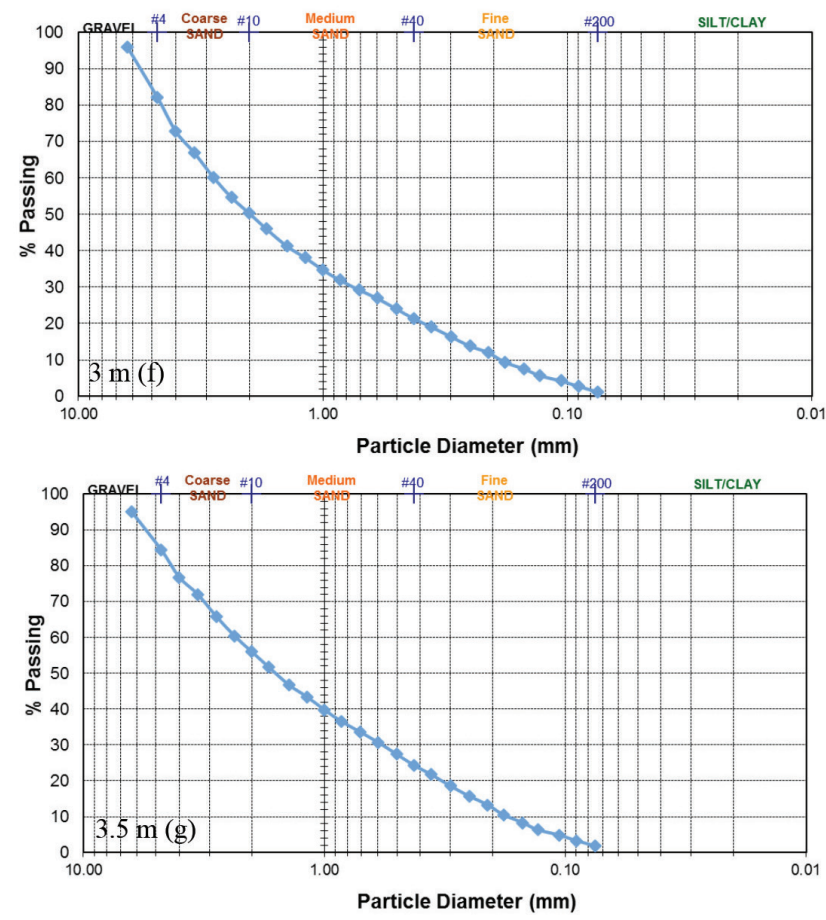

Figure 4: Grain size distribution curve at $21 \mathrm{~m}$ distance for soil sample two (SS2) at depth of (a) $0.5 \mathrm{~m}$ (b) $1 \mathrm{~m}$ (c) $1.5 \mathrm{~m}$ (d) $2 \mathrm{~m}$ (e) $2.5 \mathrm{~m}$ (f) $3 \mathrm{~m}$ (g) $3.5 \mathrm{~m}$

Figure 5 show- the soil sample three (SS3) for $7.5 \mathrm{~m}$ distance from $0.5 \mathrm{~m}$ and $1 \mathrm{~m}$ depth.

Soil sample three (SS3) at $0.5 \mathrm{~m}$ depth and the investigated soil is classified based on the grain-size distribution curve which is shown in Figure $5 \mathrm{a}: 27.3 \%$ gravel, $24.8 \%$ coarse sand, $26.6 \%$ medium sand, $18.5 \%$ fine sand and $2.6 \%$ very fine sand with coefficient of uniformity value of 18.33, coefficient of curvature value of 1.05 and hydraulic conductivity value of 0.032 $\mathrm{m} / \mathrm{s}$. This shows that the soil at this depth is more of gravel, medium sand and coarse sand than fine sand and less of very fine sand. The self-potential has a value $<-10 \mathrm{mV}$ and as the dissolved inorganic materials in water increases, self-potential becomes low.

Soil sample three (SS3) at $1 \mathrm{~m}$ depth: the investigated soil is classified based on the grain- size distribution curve with the following as shown in Figure 5b: 20.2\% gravel, 27.1\% coarse sand, $30.4 \%$ medium sand, $21.0 \%$ fine sand and $1.2 \%$ very fine sand with coefficient of uniformity value of 14.21, coefficient of curvature value of 0.93 and hydraulic conductivity value of 0.036 $\mathrm{m} / \mathrm{s}$. At this depth, it shows that the soil is more of medium sand and coarse sand than fine sand and gravel and less of very fine sand. The selfpotential has a value $<-10 \mathrm{mV}$ and an increase of the dissolved inorganic materials in water increases gives rise to low self-potential.

Table 1 shows the calculated results from particle size distribution curve for the coefficient of uniformity $\left(\mathrm{C}_{\mathrm{U}}\right)$, coefficients of curvature $\left(\mathrm{C}_{\mathrm{C}}\right)$, the hydraulic conductivities $(\mathrm{K})$ and the analysis of self-potential and the magnitude (mag). 

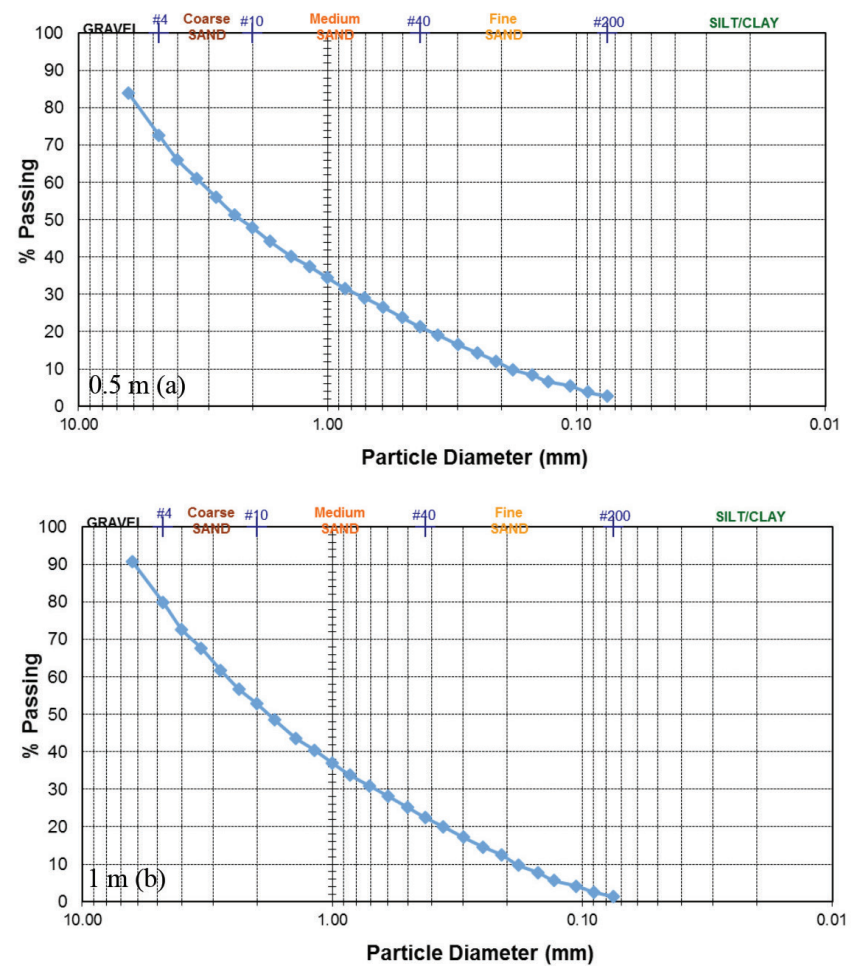

Figure 5: Grain size distribution curve at $7.5 \mathrm{~m}$ distance for soil sample three (SS3) at depth of a) $0.5 \mathrm{~m} \mathrm{~b}) 1 \mathrm{~m}$

Table 1: Summary of the grain size distribution and interpretation for soil sample SS1, SS2, SS3 and selfpotential result

\begin{tabular}{|c|c|c|c|c|c|c|c|c|c|c|c|c|}
\hline \multirow{2}{*}{$\begin{array}{c}\text { Soil } \\
\text { sample }\end{array}$} & \multirow{2}{*}{$\begin{array}{c}\text { Distance } \\
\text { (m) }\end{array}$} & \multirow{2}{*}{$\begin{array}{c}\text { Depth } \\
\text { (m) }\end{array}$} & \multicolumn{5}{|c|}{ Grain size distribution (\%) } & \multirow[t]{2}{*}{$\mathrm{Cu}_{\mathbf{U}}$} & \multirow[t]{2}{*}{$\mathbf{C c}_{\mathbf{c}}$} & \multirow{2}{*}{$\begin{array}{c}\mathbf{K} \\
(\mathrm{m} / \mathrm{s})\end{array}$} & \multirow{3}{*}{$\begin{array}{c}\text { SP } \\
\text { range } \\
\text { mV }\end{array}$} & \multirow[t]{3}{*}{ mag } \\
\hline & & & Gra & CS & MS & FS & VFS & & & & & \\
\hline & & & & & & & & & & & & \\
\hline \multirow[t]{8}{*}{ SS1 } & 2.5 & 0.5 & 18.4 & 31.2 & 31.9 & 17.6 & 0.9 & 7.39 & 1.85 & 0.053 & \multirow{7}{*}{$\begin{array}{l}-20 \text { to } \\
-15 \\
\mathrm{mV}\end{array}$} & \multirow{8}{*}{0.3} \\
\hline & & 1.0 & 11.6 & 31.3 & 43.2 & 21.9 & 1.0 & 13.53 & 1.02 & 0.029 & & \\
\hline & & 1.5 & 5.6 & 24.6 & 31.9 & 37.1 & 0.8 & 9.64 & 0.48 & 0.020 & & \\
\hline & & 2.0 & 10.9 & 33.9 & 32.4 & 21.8 & 1.0 & 13.11 & 0.59 & 0.032 & & \\
\hline & & 2.5 & 7.8 & 30.3 & 33.2 & 28.1 & 0.7 & 12.67 & 0.88 & 0.023 & & \\
\hline & & 3.0 & 7.1 & 25.3 & 35.4 & 31.4 & 0.8 & 10.71 & 0.69 & 0.020 & & \\
\hline & & 3.5 & 8.7 & 29.6 & 34.3 & 26.7 & 0.7 & 11.85 & 0.82 & 0.026 & & \\
\hline & Average & & 10.01 & 29.46 & 33.32 & 26.37 & 0.84 & 11.27 & 0.90 & 0.029 & & \\
\hline SS2 & 21 & 0.5 & 26.7 & 26.7 & 30.4 & 14.8 & 1.1 & 12.31 & 1.20 & 0.068 & & \\
\hline
\end{tabular}




\begin{tabular}{|c|c|c|c|c|c|c|c|c|c|c|c|c|}
\hline & & 1.0 & 13.6 & 30.8 & 33.7 & 20.0 & 1.4 & 12.42 & 1.06 & 0.036 & \multirow{6}{*}{$\begin{array}{l}-5 \text { to } \\
5 \mathrm{mV}\end{array}$} & \multirow{6}{*}{0.7} \\
\hline & & 1.5 & 19.0 & 24.3 & 27.2 & 28.2 & 1.2 & 15.73 & 0.57 & 0.023 & & \\
\hline & & 2.0 & 12.7 & 33.2 & 31.4 & 20.9 & 1.8 & 13.78 & 1.07 & 0.032 & & \\
\hline & & 2.5 & 18.9 & 28.9 & 28.5 & 21.2 & 2.5 & 16.75 & 0.84 & 0.026 & & \\
\hline & & 3.0 & 17.8 & 31.9 & 29.0 & 20.1 & 1.1 & 14.74 & 1.17 & 0.036 & & \\
\hline & & 3.5 & 15.6 & 28.3 & 31.8 & 22.7 & 1.6 & 13.88 & 0.87 & 0.029 & & \\
\hline & Average & & 17.76 & 29.16 & 30.20 & 21.13 & 1.53 & 14.23 & 0.97 & 0.036 & & \\
\hline \multirow[t]{4}{*}{ SS3 } & \multirow[t]{3}{*}{7.5} & 0.5 & 27.3 & 24.8 & 26.6 & 18.5 & 2.6 & 18.33 & 1.05 & 0.032 & \multicolumn{2}{|c|}{-15 to } \\
\hline & & 1.0 & 20.2 & 27.1 & 30.4 & 21.0 & 1.2 & 14.21 & 0.93 & 0.036 & -10 & \multirow[t]{2}{*}{0.5} \\
\hline & & & & & & & & & & & $\mathrm{mV}$ & \\
\hline & Average & & 23.75 & 25.95 & 28.50 & 19.75 & 1.90 & 16.27 & 0.99 & 0.034 & & \\
\hline
\end{tabular}

\section{Self-potential Result}

The output of self-potential in Figure 6 shows the high resolution of two anomalies of negative and positive, and the signals give a clear understanding that fluid motion is from higher value towards the lower value. The values of the anomalies range from $-30 \mathrm{mV}$ to $35 \mathrm{mV}$ which is related to fluid motion direction. The negative anomaly which is the low anomaly is associated with the recharge zone (infiltration) and the positive anomaly which is the high anomaly is associated with the discharge zone (Suski et al.,
2006; Mao et al., 2015; Hassan et al., 2019). Figure 6 is the contour map of self-potential which shows the water flow. Water flows from the central and southeast to the southwest part. The arrow is the combination of flow direction and magnitude, the arrowhead indicates the flow direction while the tail indicates the magnitude strength i.e. the magnitude can be short or long depending on the soil structure. The result reveals that water flows from the central and southeast to the southwest part in a lateral direction in the study area.

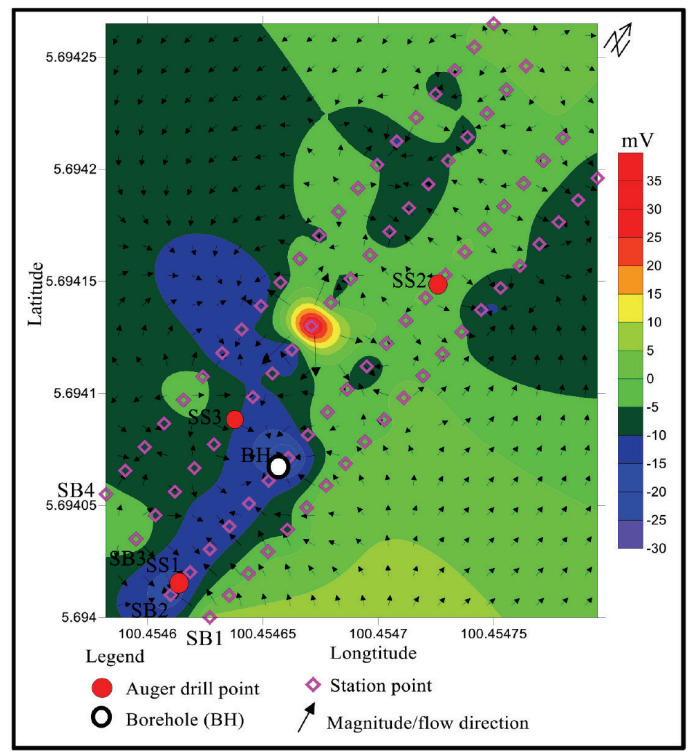

Figure 6: Contour map shows the flow of water direction generated by horizontal subsurface flow 
Figure 7 shows the magnitude of selfpotential at the auger drill point, soil sample one (SS1) at distance $2.5 \mathrm{~m}$ in SB2 with magnitude value of 0.3 and the soil type at this point is medium sand with slow water flow, soil sample two (SS2) at distance $21 \mathrm{~m}$ in SB2 with magnitude value of 0.7 and the soil type at this point is medium soil with slow water flow, and soil sample three (SS3) at distance $7.5 \mathrm{~m}$ in SB3 with magnitude value of 0.5 and the soil type at this point is medium sand with slow water flow.

In summary, the result of the Sungai Batu area shows that water flows laterally from the center and southeast to the southwest parts. The values of the anomalies of self-potential range between $-30 \mathrm{mV}$ to $35 \mathrm{mV}$ which are related to recharge and discharge activities. The low potential difference (low millivolt) $-30 \mathrm{mV}$ to $-5 \mathrm{mV}$ of the self-potential anomaly is the subsurface water flow recharge area. Therefore, the area is sandy clay with an increase in dissolved inorganic materials in water that gives low SP. The water table is shallow to the depth of $2.7 \mathrm{~m}$ in this area. SB3 shows a high magnitude of self-potential at the $13.5 \mathrm{~m}$ istance. The grain size distribution shows that the soil is composed of average percentage value of $17.17 \%$ gravel, $28.19 \%$ coarse sand, $30.67 \%$ medium sand, $22.42 \%$ fine sand and $1.42 \%$ very fine sand, which indicates that the soil consists of more medium sand, coarse sand, fine sand, gravel and less of very fine sand. The composition of the soil in terms of their proportion is medium sand $>$ coarse sand $>$ fine sand $>$ gravel $>$ very fine sand. The arrangement of the soil particles indicates the aggregate that the soil is loose and friable. It was observed from Table 1 that the soil at SS1 has more of medium sand with an average value of hydraulic conductivity of $0.029 \mathrm{~m} / \mathrm{s}$ and the magnitude is 0.3 . Both are low at this point with the self-potential value of $<-15 \mathrm{mV}$, which may be increased in dissolved inorganic materials in water. The soil at SS2 has more medium sand with an average value of hydraulic conductivity of $0.036 \mathrm{~m} / \mathrm{s}$ and the magnitude is 0.7 . Both are low at this point with the self-potential value of $<0 \mathrm{mV}$, which may be due to increasing in dissolved inorganic materials in water. The soil at SS3 has more medium sand with an average value of hydraulic conductivity of $0.034 \mathrm{~m} / \mathrm{s}$ and magnitude of 0.5 . Both are low at this point with the self-potential value of $<-10 \mathrm{mV}$, which

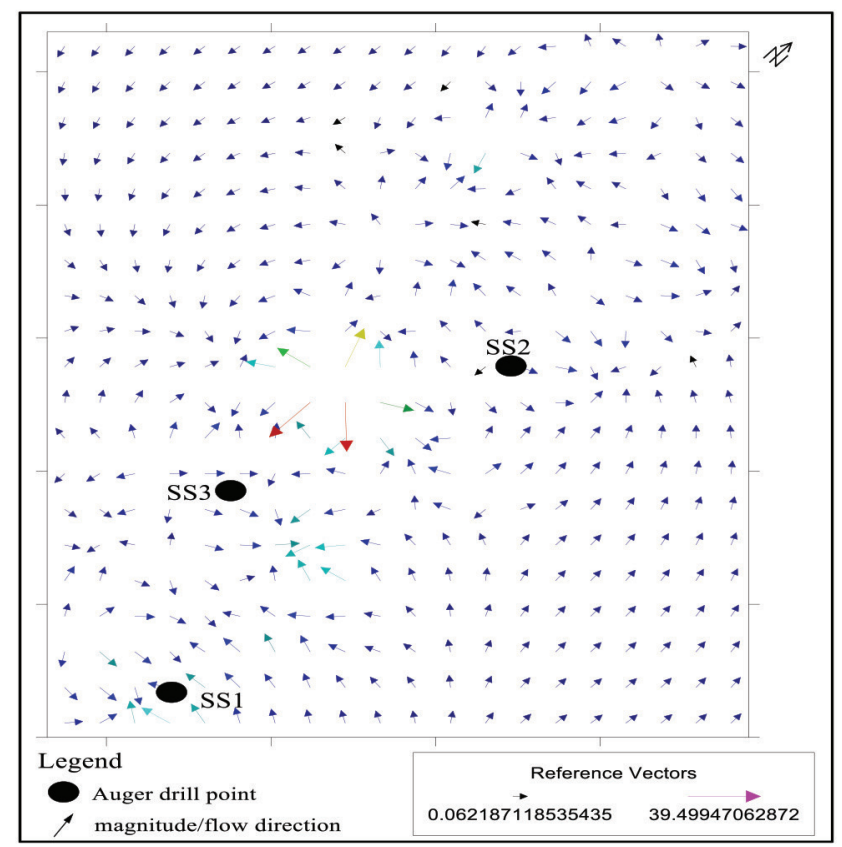

Figure 7: Magnitude of self-potential (SP) at Sungai Batu 
may be due to increasing in dissolved inorganic materials in water. The potential of water flow was determined in this area using self-potential and grain size distribution. Water flow through soil is influenced mostly by pores size, and the relative proportion of gravel, sand, silt, and clay. The self-potential interpretation shows flow direction/infiltration recharging and discharging activities which depend on soil structure and magnitude. Both results show that soil structure influences water flows in the study area. This study has been able to show the influence of the soil structure on self-potential, magnitude, and hydraulic conductivity for groundwater flow in this area.

\section{Conclusion}

The soil was composed of average percentage value of $17.17 \%$ gravel, $28.19 \%$ coarse sand, $30.67 \%$ medium sand, $22.42 \%$ fine sand and $1.42 \%$ very fine sand, from the curve of grain size distribution results which shows that the arrangement of the soil particles indicates the aggregate that the soil is loose and friable. Thus, the hydraulic conductivity $(\mathrm{K})$ value range from 0.020 to $0.053 \mathrm{~m} / \mathrm{s}$ is low, and the selfpotential magnitude value ranging from 0.3 to 0.7 is low. The soil type in this area is more of medium sand with low hydraulic conductivity and self-potential magnitude. Therefore, this study has been able to show the importance of self-potential, magnitude, and hydraulic conductivity which provide precise knowledge of the source of water flow, flow pattern, soil structure influence, and the relationship between hydraulic conductivity and selfpotential magnitude which will strengthen water management in the study area and can be used when faced with engineering and environmental problems.

\section{Acknowledgements}

The authors would like express their appreciation to Universiti Sains Malaysia (USM) for funding the project with grant FRGS and RUI with grant number 203.PFIZIK.6711663 and 1001/ PFIZIK/8011110. The authors would also like to acknowledge the assistance given by the School of Physics, the Oceanography laboratory for provision of the equipment used for analyzing the samples and special thanks to Geophysics Laboratory Staff and Geophysics Postgraduate Team for their full support in data and soil sample collections.

\section{References}

Adeeko, T. O., Muztaza, N. M., Zakaria, T. M., \& Ismail, N. (2018). Correlation of self-potential and ground magnetic survey techniques to investigate fluid seepage in archaeological site, Sungai Batu, Lembah Bujang, Kedah, Malaysia. Natural and Engineering Sciences, 3(2), 196-206.

Alakayleh, Z., Clement, P. T., \& Fang, X. (2018). Understanding the changes in hydraulic conductivity values of coarse- and finegrained porous media mixtures. Water, 10, 313. doi:10.3390/w10030313

Alamta, S., Mitra, D., \& Fitri, M. (2012). Fluid flow direction beneath geothermal area based on self-potential data (A case study at mount patuha, west Java, Indonesia). International Journal of Geology, 6(1), 2636.

Bohling, G. C., \& Butler, J. (2010). Inherent limitations of hydraulic tomography. Ground Water, 48, 809-824.

Bol'eve, A., Revil, A., Janod, F., Mattiuzzo, J. L., \& Jardani, A. (2007). Forward modelling and validation of a new formulation to compute self-potential signals associated with ground water flow. Hydrology and Earth System Sciences, 11, 1661-1671.

Brauchler, R., Hu, R., Hu, L., Jinenez, S., Bayer, P., Dietrich, P., \& Ptak, T. (2013). Rapid field application of hydraulic tomography for resolving aquifer heterogeneity in unconsolidated sediments. Water Resources Research, 49(4), 2013-2024. doi:10.1002/ wrcr.20181.

Cabalar, A. F., \& Akbulut, N. (2016). Evaluation of actual and estimated hydraulic 
conductivity of sands with different gradation and shape. Springer Plus, 5, 820. doi:10.1186/s40064-016-2472-2

Carrier, W. D. (2003). Goodbye, Hazen; Hello, Kozeny-Carman. Journal of Geotechnical and Geoenvironmental Engineering (C) ASCE / November 2003, Technical Notes, 1054-1056. doi: 10.1061/ ASCE!10900241 2003!129:11 1054!

Chapuis, R. P. (2012). Predicting the saturated hydraulic conductivity of soils: A review. Bulletin of Engineering Geology and the Environment, 71(3), 401-434.

Daniel, D. E. (1989). In situ hydraulic conductivity tests for compacted clay. Journal of Geotechnical Engineering, 115(9).

Emujakporue, G. O. (2016). Self-potential investigation of contaminants in a dumpsite, University of Port Harcourt, Nigeria. World Scientific News, 57(2016), 140-148.

Essa, K. S., \& Elhussein, M. (2017). A new approach for the interpretation of selfpotential data by 2-D inclined plate. Journal of Applied Geophysics, 136(2017), 455-461.

Fagerlund, F., \& Heinson, G. (2003). Detecting subsurface groundwater flow in fractured rock using self-potential (SP) methods. Environmental Geology, 43, 782-794. doi 10.1007/s00254-002-0693-x

Fauziah, A., Ahmad, S. Y., \& Farooqi, M. A. (2006). Characterization and geotechnical properties of Penang residual soils with emphasis on landslides. American Journal of Environmental Sciences, 2(4), 121-128.

Fetter, C. W. (2001). Applied hydrogeology (4th ed.). New Jersey: Prentice Hall.

Gao, Q., Shang, Y., Hasan, M., Jin, W., \& Yang, P. (2018). Evaluation of a weathered rock aquifer using ERT method in south guangdong, China. Water, 10, 293. doi:10.3390/w10030293

Giampaolo, V., Calabrese, D., \& Rizzo, E. (2016). Transport processes in porous media by self-potential method. Applied and Environmental Soil Science, 2016, Article ID 3951486, 1-12. http://dx.doi. org $/ 10.1155 / 2016 / 3951486$

Google earth. (2018). US department of state geographer.

Gokturkler, G., \& Balkaya, C. (2012). Inversion of self-potential anomalies caused by simple-geometry bodies using global optimization algorithms. Journal of

Geophysics and Engineering, 9(2012), 498-507.

Harry, T. A., Ushie, F. A., \& Agbasi, O. E. (2018). Hydraulic and geoelectric relationships of aquifers using vertical electrical sounding (VES) in parts of Obudu, Southern Nigeria. World Scientific News, 94(2), 261-275.

Hasan, M., Shang, Y., Jin, W., \& Akhter, G. (2019). Investigation of fractured rock aquifer in south china using electrical resistivity tomography and self-potential methods. Journal of Mountain Science, 16(4), 850-869. https://doi.org/10.1007/ s11629-018-5207-8

Hussain, F., \& Nabi, G. (2016). Empirical formulae evaluation for hydraulic conductivity determination based on grain size analysis. Pyrex Journal of Research in Environmental Studies, 3(3), 026-032.

Hazen, A. (1982). Some physical properties of sands and gravels, with special reference to their use in filtration. 24th Annual Report, Massachusetts State Board of Health, Pub. Doc.34, 539-556.

Idris, M. G., Abba, S. I., Said, B. U., \& Abdullahi, M. B. (2015). The underground water investigations using self-potential geophysical survey a case study of BUK old campus by the application of computer modeling software (Matlab) Kano, Nigeria. International Journal of Advanced Technology in Engineering and Science, 3(1), 680-691.

Ikard, S. J., Revil, A., Schmutz, M., Karaoulis, M., Jardani, A., \& Mooney, M. (2013). 
Characterization of focused seepage through an earth fill dam using geoelectrical methods. Ground Water, 52(6), 952-965.

Ishaku, J. M., Gadzama, E. W., \& Kaigama, U. (2011). Evaluation of empirical formulae for the determination of hydraulic conductivity based on grain-size analysis. Journal of Geology and Mining Research, 3(4), 105-113.

Jardani, A., Dupont, J. P., \& Revil, A. (2006). Self-potential signals associated with preferential groundwater flow pathways in sinkholes. Journal of Geophysical Research, 111, B09204, doi:10.1029/2005JB004231

Jougnot, D., Linde, N., Looms, M. C., \& Haarder, E. B. (2015). Monitoring of saline tracer movement with vertically distributed self-potential measurements at the HOBE agricultural site, voulund, Denmark. Journal of Hydrology, 521, 314-327. doi:10.1016/j.jhydrol.2014.11.041.

Jouniaux, L., Maineult, A., Naudet, V., Pessel, M., \& Sailha, P. (2009). Review of selfpotential methods in hydrogeophysics. Geoscience, 341(2009), 928-936.

Khodzori, F. A., Saad, S., \& Mohammadnoor, N. (2019). Coral community structure in payar Island Marine Park, Malaysia. Journal of Sustainability Science and Management, 14(1), 29-39.

Linde, N., Doetsch, J., Jougnot, D., Genoni, O., D“urst, Y., Minsley, B. J., Vogt, T., Pasquale, N., \& Luster, J. (2011). Self-potential investigations of a gravel bar in a restored river corridor. Hydrology and Earth System Sciences, 15, 729-742. doi:10.5194/hess15-729-2011

Lopez, O. M., Jadoon, K. Z., \& Missimer, T. M. (2015). Method of relating grain size distribution to hydraulic conductivity in dune sands to assist in assessing managed aquifer recharge projects: Wadi Khulays Dune Field, Western Saudi Arabia. Water, 7, 6411-6426. doi:10.3390/w7116411
Malama, B. (2014). Theory of transient streaming potentials in coupled unconfined aquifer-unsaturated zone flow to a well. Water Resources Research, 50, 2921-2945. doi:10.1002/ 2013WR014909.

Martínez-Pagán, P., Jardani, A., Revil, A., \& Haas, A. (2010). Self-potential monitoring of a salt plume. Geophysics, 75(4), WA17WA25.

Maineult, A., Jouniaux, L., \& Bernabe', Y. (2006). Influence of the mineralogical composition on the self-potential response to advection of $\mathrm{KCl}$ concentration fronts through sand. Geophysical Research Letters, 33, L24311. doi:10.1029/2006GL028048

Mao, D., Revil, A., Hort, R. D., Munakata-marr, J., Atekwana, E. A., \& Kulessa, B. (2015). Resistivity and self-potential tomography applied to groundwater remediation and contaminant plumes: Sandbox and field experiments. Journal of Hydrology, 530, $1-14$.

Mehanee, S. A. (2015). Tracing of paleo-shear zones by self-potential data inversion: Case studies from the KTB, Rittsteig, and Grossensees graphite-bearing fault planes. Earth, Planets and Space 67, 14. doi 10.1186/s40623-014-0174-y

Moore, J. R., Boleve, A., Sanders, J. W., \& Glaser, S. D. (2011). Self-potential investigation of moraine dam seepage. Journal of Applied Geophysics, 74(2011), 277-286.

Morin, R. H. (2006). Negative correlation between porosity and hydraulic conductivity in sand-and-gravel aquifers at Cape Cod, Massachusetts, USA. Journal of Hydrology, 316(2006), 43-52. doi:10.1016/j.jhydrol.2005.04.013

Mohd, H. M., Faten, N. U. Z. A., Ahmad, J., \& Mohd, A. A. R. (2019). Landslide susceptibility mapping at lebir and galas river basins after extreme flood event using weights of evidence. Journal of Sustainability Science and Management, 14(2), 103-115. 
Muhammad, N. A. (2019). The influence of precipitation, stream discharge, and physiographic factors on flood vulnerability at cimanuk river-west Java, Indonesia. Journal of Sustainability Science and Management, 14(1), 125-136.

Muztaza, N. M., Adeeko, T. O., Saharudin, M. A., Sulaiman, N., \& Ismail, N. E-H. (2018). The application of 2-D resistivity and selfpotential (SP) methods in determining the water flow. Journal of Physics: Conference Series 995. doi:10.1002/2014RG000465

Nabi-Sichani, N., \& Sepaskhah, A. R. (2012). Evaluation of different methods for the determination of saturated hydraulic conductivity for simulation of water table depth and drainage discharge using the DRAINMOD computer simulation model. Archives of Agronomy and Soil Science, 58(8), 887-901, doi:10.1080/03650340.20 10.550282

Nimmo, J. R., Schmidt, K. M., Perkins, K. S., \& Stock, J. D. (2009). Rapid measurement of field saturated hydraulic conductivity for areal characterization. Vadose Zone Journal, 8(1), 142-149.

Odong, J. (2008). Evaluation of empirical formulae for determination of hydraulic conductivity based on grain-size analysis. The Journal of American Science, 4(1), ISSN 1545-1003.

Olivetiand, I., \& Cardarelli, E. (2017). 2D approach for modelling self-potential anomalies: Application to synthetic and real data. Bollettino di Geofisica Teorica ed Applicata, 58(4), 415-430. doi10.4430/ bgta0198

Putvance, D. T. (2000). On the electricalhydraulic conductivity correlation in aquifers. Water Resources Research, 36(10), 2905-2913.

Revil, A., Naudet, V., Nouzaret, J., \& Pessel, M. (2003). Principles of electrography applied toself-potential electrokinetic sources and hydrogeological applications.
Water Resources Research, 39(5), 1114. doi:10.1029/2001WR000916

Revil, A., \& Leroy, P. (2004). Constitutive equations for ionic transport in porous shales. Journal of Geophysical Research, 109, B03208, doi:10.1029/2003JB002755.

Reynolds, W. D., \& Elrick, D. E. (1990). Ponded infiltration from a single ring: I. Analysis of steady flow. Soil Science Society of America Journal, 54(5), 1233-1241.

Roudsari, M. S., \& Beitollahi, A. (2015). Laboratory modelling of self-potential anomalies due to spherical bodies. Exploration Geophysics, 46, 320-331.

Rosas, J., Lopez, O., Missimer T. M, Coulibaly, K., Dehwah, A. H. A., Sesler, K., Lujah, L.

R., \& Mantilla, D. (2014). Hydraulic conductivity and grain size distribution: comparison of methods for different sedimentary depositional environments. Groundwater, 52, 399-413.

Salarashayeri, A. F., \& Siosemarde, M. (2012). Prediction of soil hydraulic conductivity from particle-size distribution. International Journal of Geological and Environmental Engineering, 6(1), 16-20.

Skianis, G. A. (2012). The self-potential anomaly produced by a subsurface flow at the contact of two horizontal layers and its quantitative interpretation. International Journal of Geophysics, 2012(5), Article ID 483590, 1-8. doi:10.1155/2012/483590

Song, J, Chen, X, Cheng, C, Wang, D., Lackey, S., \& Xu, Z. (2009). Feasibility of grainsize analysis methods for determination of vertical hydraulic conductivity of streambeds. Journal of Hydrology, 375(2009), 428-437.

Soueid, A. A., Jardani, A., Revil, A., \& Dupont, J. P. (2014). Hydraulic conductivity field characterization from the joint inversion of hydraulic heads and self-potential data. Water Resources Research, 50, 3502-3522. doi:10.1002/2013WR014645 
Srivastava, S., \& Agarwal, B. N. P. (2009). Interpretation of self-potential anomalies by enhanced local wave number technique. Journal of Applied Geophysics, 68(2009), 259-268.

Straface, S., Rizzo, E., \& Chidichimo, F. (2010). Estimation of hydraulic conductivity and water table map in a large-scale laboratory model by means of the self $\square$ potential method. Journal of Geophysical Research, 115, B06105. doi:10.1029/2009JB007053

Suski, B., Revil, A., Titov, K., Konosavsky, P., Voltz, M., Dage's, C., \& Huttel, O. (2006). Monitoring of an infiltration experiment using the self-potential method.
Water Resource Research, 42, W08418. doi:10.1029/2005WR004840.

Tanguy, R., Alain, D., Serge, B., Olivier, K., Vincent, H., \& Frederic, N. (2011). Assessing the contribution of Electrical Resistivity Tomography (ERT) and Self-Potential (SP) methods for a water well drilling program in fractured/karstified limestones. Journal of Applied Geophysics, 75(1), 42-53. doi: 10.1016/j.jappgeo.2011.06.0081687-885X: $1-10$

Voytek, E. B., Rushlow, C. R., Godsey, S. E., \& Singha, K. (2016). Identifying hydrologic flowpaths on arctic hillslopes using electrical resistivity and self-potential. Geophysics, 81(1), WA225-WA232. 